\title{
STUDIES OF CHEMICAL CLEANING ON HISTORICAL LEAD
}

\author{
Kristýna Charlotte STRACHOTOVÁ, Milan KOUŘIL, Jan ŠVADLENA, Šárka MSALLAMOVÁ \\ University of Chemistry and Technology, Prague, Department of Metals and Corrosion Engineering, Prague, \\ Czech Republic, EU, strachok@vscht.cz
}

https://doi.org/10.37904/metal.2019.949

\begin{abstract}
This study has been focused on the evaluation and comparison of the chemical treatments applied (aqueous solutions of $\mathrm{CH}_{3} \mathrm{COOH}(1 \%), \mathrm{CH}_{3} \mathrm{COONH}_{4}(5 / 25 \%)$, EDTA (3/5\%), $\mathrm{HCl}(5 / 10 \%)$ and ion exchange resin) or possible applicable $\left(\mathrm{H}_{2} \mathrm{SO}_{4}, \mathrm{Na}_{3} \mathrm{PO}_{4} \cdot 12 \mathrm{H}_{2} \mathrm{O}\right.$ or $\left.\mathrm{KNaC}_{4} \mathrm{H}_{4} \mathrm{O}_{6} \cdot 4 \mathrm{H}_{2} \mathrm{O}\right)$ to the heritage of lead stored in museums. The evaluation of the different solutions used for chemical treatment on lead samples is based on lead surface changes (colour, morphology, chemical composition) observation and on the impact of the chemical treatments (mass loss and cleaning efficiency). Examination of the lead samples before and after different chemical treatments showed that each of used solutions induced any chemical and/ or physical changes.
\end{abstract}

Keywords: Lead, chemical cleaning, chemical treatment, pickling, passivity

\section{INTRODUCTION}

Lead has been highly employed from ancient times to the present day (various artefacts of everyday life, statues, coins, organ pipes, stained glass) [1-5]. Due to its high corrosion resistance, many of these artefacts are stored in museums and archives [1-12]. The major risk to historical lead is acetic acid which concentration could be up to 20 times higher in museum environment than outdoors [4]. In the presence of acetic acid lead corrodes while voluminous corrosion products (mainly cerussite, hydrocerussite or plumbonacryte) without protective properties are formed [1-12]. Due high humidity acetic acid should be at least partly released from corrosion products and further lead corrosion process occurs $[1,3,4,7]$. Cleaning of corroded lead artefacts may be necessary either to stop the active corrosion and to restore its legibility and aesthetic appearance [4]. The chemical treatment of corroded lead prevents poisoning by inhalation of toxic lead corrosion products (compared to mechanical cleaning) and does not required any specific equipment and the skills of the conservator (compared to electrochemical cleaning) [4]. In the past the "Caley method" (aqueous solution of $\mathrm{HCl}(1: 10)$ ) or aqueous solution of $\mathrm{H}_{2} \mathrm{SO}_{4}, \mathrm{CH}_{3} \mathrm{COOH}$ or $\mathrm{CH}_{3} \mathrm{COONH}_{4}$ to remove corrosion products from lead surface were employed. Now is frequently used chelating agent EDTA (aqueous solution $3-10 \% \mathrm{w} / \mathrm{w}$ ) $[3,4,6]$. In order to find the best way to remove corrosion product from historical lead surface due to chemical treatment was this research done.

\section{EXPERIMENTAL PART}

\subsection{Samples}

Lead samples ( $\mathrm{Pb} 99.9 \%$ ) in dimensions $10 \times 50 \times 1 \mathrm{~mm}$ were used in this work. The evaluation of the different solutions used for chemical cleaning was carried out on lead samples with a pure lead surface and on lead samples with artificially prepared corrosion products (corroded lead samples). The pure lead surface was obtained with grinding of the surface with abrasive wadding (3M Scotch-Brite CF-MF), subsequent rinsing with ethanol and then air drying. The corroded surface was obtained by immersing the non-treated lead samples into $\mathrm{HNO}_{3}(65 \% \mathrm{w} / \mathrm{w})$ for 20 minutes, subsequent fast replace (without rinsing by distilled water or another solution) of lead samples into $\left(\mathrm{NH}_{4}\right)_{2} \mathrm{CO}_{3}$ solution $\left(5 \mathrm{~g}\right.$ of $\left(\mathrm{NH}_{4}\right)_{2} \mathrm{CO}_{3} / 100 \mathrm{ml}$ of distilled water) and immersing in this for 24 hours, subsequent rinsing by distilled water and ethanol and air drying. The surface composition of corroded lead samples was analysed by X-ray diffraction (XRD) with a X'Pert PRO diffractometer and 
HighScore Plus software (Malvern Panalytical Ltd.). They presented $27 \mathrm{wt} \%$ of lead, $71 \mathrm{wt} \%$ of cerussite $\left(\mathrm{PbCO}_{3}\right)$ and $2 \mathrm{wt} \%$ of hydrocerussite $\left(\mathrm{Pb}_{3}\left(\mathrm{CO}_{3}\right)_{2}(\mathrm{OH})_{2}\right)$.

\subsection{Chemical cleaning}

As evaluated solutions for chemical cleaning were used aqueous solutions of acetic acid $\left(\mathrm{CH}_{3} \mathrm{COOH}\right) 1 \%$ $\mathrm{w} / \mathrm{w}$, ammonium acetate $\left(\mathrm{CH}_{3} \mathrm{COONH}_{4}\right) 5$ and $25 \% \mathrm{w} / \mathrm{w}$, chelating agent EDTA $\left(\mathrm{C}_{10} \mathrm{H}_{16} \mathrm{~N}_{2} \mathrm{O}_{8}\right) 3$ and $10 \% \mathrm{w} / \mathrm{w}$, hydrochloric acid $(\mathrm{HCl}) 5$ and $10 \% \mathrm{w} / \mathrm{w}$, sulfuric acid $\left(\mathrm{H}_{2} \mathrm{SO}_{4}\right) 10 \% \mathrm{w} / \mathrm{w}$, sodium phosphate dodecahydrate $\left(\mathrm{Na}_{3} \mathrm{PO}_{4} \cdot 12 \mathrm{H}_{2} \mathrm{O}\right) 15 \% \mathrm{w} / \mathrm{w}$, Rochelle salt $\left(15 \mathrm{~g} \mathrm{KNaC}_{4} \mathrm{H}_{4} \mathrm{O}_{6} \cdot 4 \mathrm{H}_{2} \mathrm{O}+5 \mathrm{~g} \mathrm{NaOH} / 100 \mathrm{ml}\right.$ of distilled water) and ion exchange resin PMB 102-2 (Waterfilter s.r.o.) (50 g PMB 102-2/100 ml of distilled water). The solutions of acetic acid and sodium phosphate dodecahydrate were used boiling. The ion exchange resin and both of ammonium acetate solutions were used at $60^{\circ} \mathrm{C}\left( \pm 5^{\circ} \mathrm{C}\right)$. The others were used at room temperature.

Lead samples with pure lead surface were treated by immersion into different solutions for chemical cleaning for 1 hour (without interruption), subsequent rinsing by distilled water and ethanol and air drying. The corroded lead samples were treated by cyclically interrupted immersion into different solutions for chemical cleaning (interval pickling), after each interruption the samples were rinsed by distilled water and ethanol and air dried. The pickling intervals (in minutes): 1-1-1-1-1-1-2-2-2-3-5-5-5-10-10-10. Overall the corroded lead sample was immersed into the solution for chemical cleaning for 1 hour also.

\subsection{Characterization techniques}

The samples were characterized before and after full treatment by different techniques such as gravimetry, colorimetry, optical microscopy (OM), scanning electron microscopy (SEM) and infrared (IR) spectroscopy.

All samples were weighted to determine the mass loss during treatment. Mass loss is calculated with equation (1). Lead samples with corroded surface were weighted after each cycle of sample immersion (number of cycles: 16), lead samples with pure lead surface were weighted after 1 hour of sample immersion (number of cycles: 1$)$.

$$
\Delta m=m_{\text {treated lead }}-m_{\text {original lead }}
$$

where: $\Delta m$ - the mass loss of the sample during treatment $(\mathrm{g})$;

$m_{\text {treated lead }}$ - the mass of the sample after each cycle of sample immersion $(\mathrm{g})$;

$m_{\text {original lead }}$ the mass of the sample before treatment $(\mathrm{g})$.

Konica Minolta spectrophotometer CM-700d measured the chromatic properties of the samples. Results were expressed using the CIE-L*a*b* colorspace with Specular Component Included (SCl). Three spectra were acquired from each side of the sample and averaged.

The chemical composition of the surface was analyzed by FT-IR spectrometer Nicolet NEXUS with Omnic Specta software.

Samples surface was observed by optical microscope Olympus PME 3 and surface morphology was observed by SEM Tescan VEGA 3.

\section{RESULTS AND DISCUSSION}

\subsection{Gravimetry}

Chemical cleaning should be designed to remove all corrosion products without mass loss of base metal. However, according to Figure 1 all used chemical treatments produced mass loss of lead samples. The most aggressive treatment with high loss of material were $\mathrm{CH}_{3} \mathrm{COONH}_{4}(25 \%)$ and $\mathrm{HCl}(5 \%)$ solutions. On the contrary small mass loss during full treatment procedure reported both $\mathrm{H}_{2} \mathrm{SO}_{4}$ solutions. $\mathrm{CH}_{3} \mathrm{COOH}$, 
$\mathrm{KNaC}_{4} \mathrm{H}_{4} \mathrm{O}_{6} \cdot 4 \mathrm{H}_{2} \mathrm{O}$ and EDTA (10 \%) solutions removed corrosion products during 1 - 2 treatment cycle and after this produced a small mass loss of base lead. The nonlinear mass loss produced mainly by both $\mathrm{CH}_{3} \mathrm{COONH}_{4}$ and $\mathrm{Na}_{3} \mathrm{PO}_{4} \cdot 12 \mathrm{H}_{2} \mathrm{O}, \mathrm{H}_{2} \mathrm{SO}_{4}(20 \%), \mathrm{CH}_{3} \mathrm{COOH}$ and ion exchange resin should be due to active lead surface cleaning left and new $\mathrm{PbO}$ surface layer after cleaning fast formed.

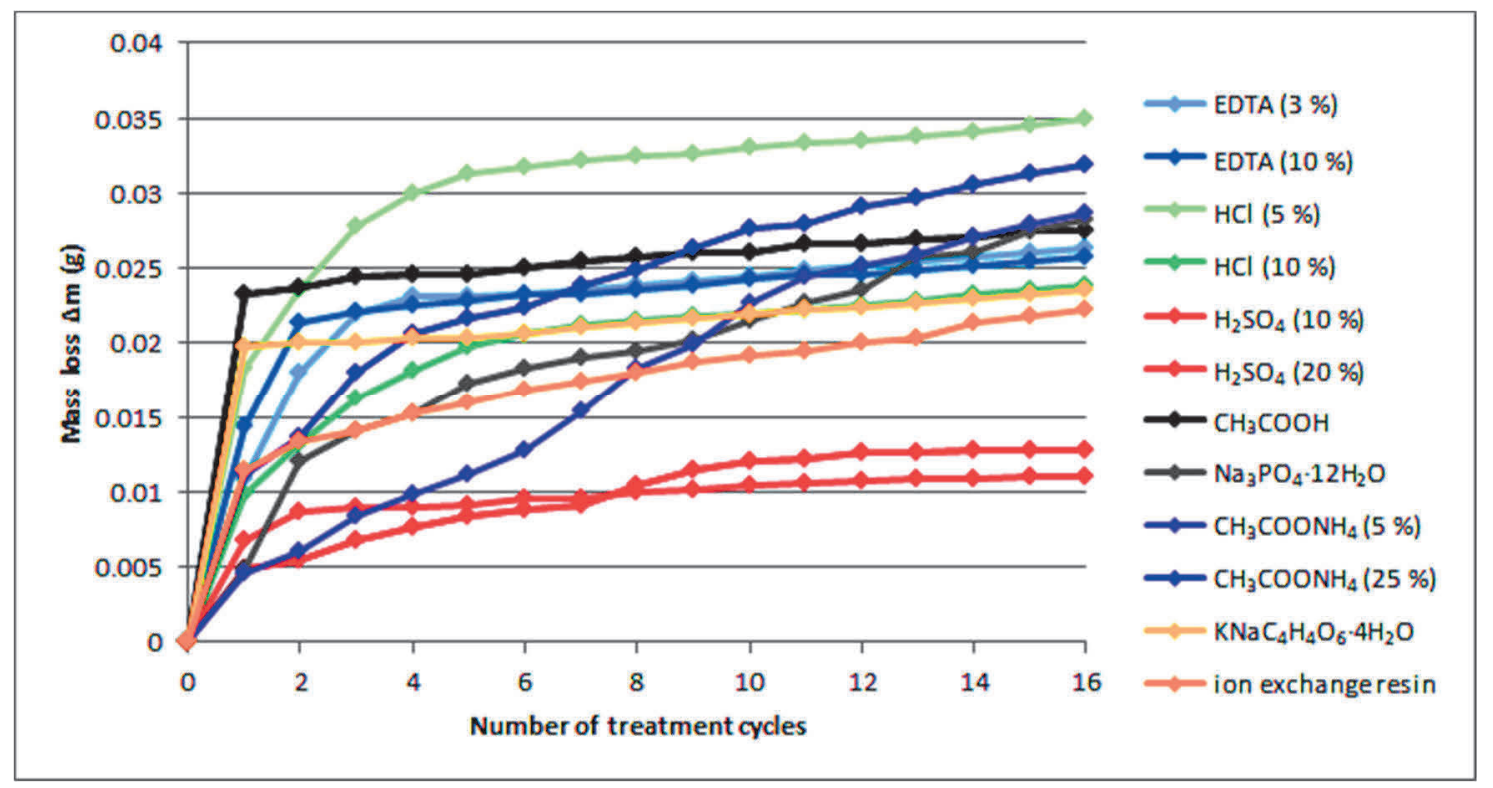

Figure 1 The mass loss of lead samples with corroded surface as a function of the number of treatment cycles

Table 1 Corrosion rates (ng/year) of lead samples immersed in different solutions for chemical cleaning measured on samples with corroded surface during corrosion products removal (0-1 treatment cycles) and after corrosion products removal (14-15 treatment cycles) or on samples with pure lead surface during full treatment

\begin{tabular}{|c|c|c|c|}
\hline \multirow{2}{*}{$\begin{array}{c}\text { chemical cleaning } \\
\text { solution }\end{array}$} & \multicolumn{2}{|c|}{ lead samples with corroded surface } & samples with pure lead surface \\
\cline { 2 - 4 } & $0-1$ treatment cycles & $14-15$ treatment cycles & 0.02 \\
\hline EDTA $(3 \%)$ & 20.55 & 0.38 & 0.02 \\
\hline EDTA (10 \%) & 27.21 & 0.57 & 0.04 \\
\hline $\mathrm{HCl}(5 \%)$ & 34.82 & 0.95 & 0.03 \\
\hline $\mathrm{HCl}(10 \%)$ & 18.65 & 0.57 & 0.00 \\
\hline $\mathrm{H}_{2} \mathrm{SO}_{4}(10 \%)$ & 12.94 & 0.02 & 0.00 \\
\hline $\mathrm{H}_{2} \mathrm{SO}_{4}(20 \%)$ & 9.13 & 0.02 & 0.03 \\
\hline $\mathrm{CH}_{3} \mathrm{COOH}$ & 44.14 & 0.76 & 0.01 \\
\hline $\mathrm{Na}_{3} \mathrm{PO}_{4} \cdot 12 \mathrm{H}_{2} \mathrm{O}$ & 9.32 & 2.66 & 0.03 \\
\hline $\mathrm{CH}_{3} \mathrm{COONH}_{4}(5 \%)$ & 8.56 & 1.90 & 0.02 \\
\hline $\mathrm{CH}_{3} \mathrm{COONH}_{4}(25 \%)$ & 21.31 & 1.33 & 0.02 \\
\hline $\mathrm{KNaC}_{4} \mathrm{H}_{4} \mathrm{O}_{6} \cdot 4 \mathrm{H}_{2} \mathrm{O}$ & 37.48 & 0.95 & 0.01 \\
\hline lon exchange resin & 21.88 & 1.14 & \\
\hline
\end{tabular}

According to corrosion rates reported in Table 1 both $\mathrm{HCl}, \mathrm{CH}_{3} \mathrm{COOH}$ and $\mathrm{CH}_{3} \mathrm{COONH}_{4}$ (5 \%) solutions were very aggressive and both $\mathrm{H}_{2} \mathrm{SO}_{4}, \mathrm{Na}_{3} \mathrm{PO}_{4} \cdot 12 \mathrm{H}_{2} \mathrm{O}$ solutions and ion exchange resin non-aggressive to samples 
with pure lead surface. In the presence of corrosion products on lead sample surface both $\mathrm{H}_{2} \mathrm{SO}_{4}$, $\mathrm{Na}_{3} \mathrm{PO}_{4} \cdot 12 \mathrm{H}_{2} \mathrm{O}$ and $\mathrm{CH}_{3} \mathrm{COONH}_{4}(5 \%)$ solutions were non-aggressive. After corrosion products removal both EDTA, $\mathrm{HCl}(10 \%)$ and both $\mathrm{H}_{2} \mathrm{SO}_{4}$ solutions were non-aggressive for base lead (Table 1 and Figure 1).

\subsection{Surface characterization}

According to mass loss data all used chemical treatments look effectively. Nevertheless, optical microscopy of corroded samples after full chemical treatment reported both $\mathrm{H}_{2} \mathrm{SO}_{4}$ and $\mathrm{Na}_{3} \mathrm{PO}_{4} \cdot 12 \mathrm{H}_{2} \mathrm{O}$ solutions and ion exchange resin as non-efficient chemical cleaning agents due to corrosion products on lead samples after treatment presence (Figure 2). In the case of ion exchange resin the new texture on the treated sample surface (there are pure lead surface pits (the place with resin and sample contact) between corrosion products (the place without resin and sample contact)) occurred. The brown tarnishing on sample surface after 24 hours after treatment of the sample in $\mathrm{CH}_{3} \mathrm{COONH}_{4}(25 \%)$ solution occurred (Figure 2).
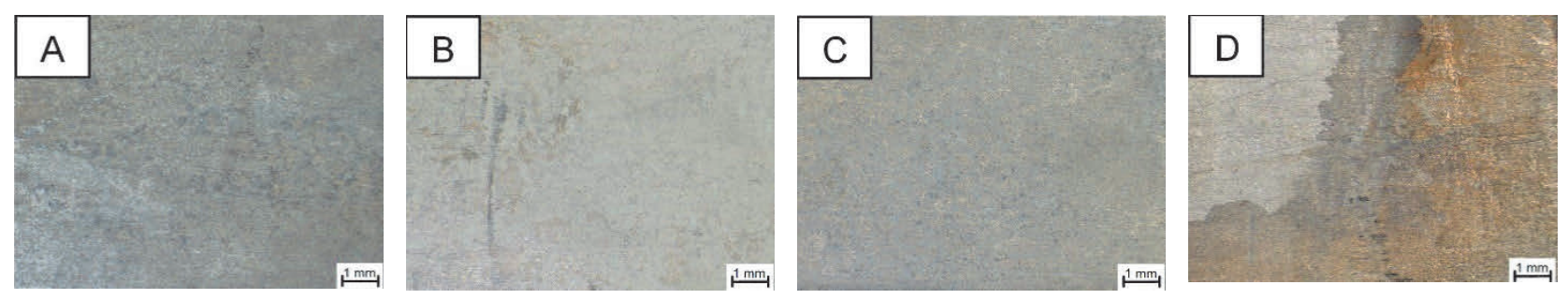

Figure 2 The optical microscopy of artificially corroded lead samples after chemical treatment in $\mathrm{H}_{2} \mathrm{SO}_{4}(10 \%)$ solution (A), $\mathrm{Na}_{3} \mathrm{PO}_{4} \cdot 12 \mathrm{H}_{2} \mathrm{O}$ solution (B), ion exchange resin (C) and $\mathrm{CH}_{3} \mathrm{COONH}_{4}(25 \%)$ solution (D)

Chemical cleaning have to leaving original colour of base material. Nevertheless used chemical treatments caused a significant gloss change on treated samples (except samples treated with $\mathrm{Na}_{3} \mathrm{PO}_{4} \cdot 12 \mathrm{H}_{2} \mathrm{O}$ and both $\mathrm{H}_{2} \mathrm{SO}_{4}$ solutions and ion exchange resin, which did not remove the corrosion products). The sample with pure lead surface had higher gloss value. The variation of luminosity and chromatic variation on treated samples and sample with pure lead surface was low (except samples treated with $\mathrm{Na}_{3} \mathrm{PO}_{4} \cdot 12 \mathrm{H}_{2} \mathrm{O}$ and both $\mathrm{H}_{2} \mathrm{SO}_{4}$ solutions and ion exchange resin) because the chemical cleaning agents removed all corrosion products on the sample exposing pure lead surface.

The SEM observation confirms for the corroded samples treated with $\mathrm{Na}_{3} \mathrm{PO}_{4} \cdot 12 \mathrm{H}_{2} \mathrm{O}$ solution and ion exchange resin the artificial corrosion products presence. On samples treated in $\mathrm{H}_{2} \mathrm{SO}_{4}$ solutions the formation of new globular crystals was by SEM observed (Figure 3). Chemical treatment of corroded samples in $\mathrm{CH}_{3} \mathrm{COOH}$ solution artificially corrosion products removed and new lamellar corrosion products formed (Figure 3). Further chemical treatment agents (both EDTA, both $\mathrm{HCl}$, both $\mathrm{CH}_{3} \mathrm{COONH}_{4}$ and $\mathrm{KNaC}_{4} \mathrm{H}_{4} \mathrm{O}_{6} \cdot 4 \mathrm{H}_{2} \mathrm{O}$ ) induced very heterogeneous surface on samples where original surface scratches were deepened and lots of pits were produced (Figure 3).

FT-IR analyse spectra for the corroded samples treated with $\mathrm{Na}_{3} \mathrm{PO}_{4} \cdot 12 \mathrm{H}_{2} \mathrm{O}$ and $\mathrm{CH}_{3} \mathrm{COOH}$ solution and ion exchange resin did not reveal any significant changes with referent corroded lead sample spectrum. The spectra indicate the presence of lead oxide and lead carbonates. On the contrary spectra for corroded samples treated with another chemical treatment agents (both $\mathrm{HCl}$, both $\mathrm{CH}_{3} \mathrm{COONH}_{4}$ and $\mathrm{KNaC}_{4} \mathrm{H}_{4} \mathrm{O}_{6} \cdot 4 \mathrm{H}_{2} \mathrm{O}$ ) were similar to spectrum for referent sample with pure lead surface. These spectra indicate the presence of lead oxide due to the fast passivation of lead in atmospheric conditions. FT-IR spectroscopy for corroded samples treated with both $\mathrm{H}_{2} \mathrm{SO}_{4}$ solutions confirmed corrosion products chemical composition changing observed by SEM. The spectra indicate the presence of lead sulphate. The spectra obtained for corroded samples treated with EDTA solutions indicate the significant decrease in the intensity of lead oxide peaks and the presence of amine groups in the spectra were also observed. The spectra indicate remains of EDTA adsorbed on lead sample surface. 

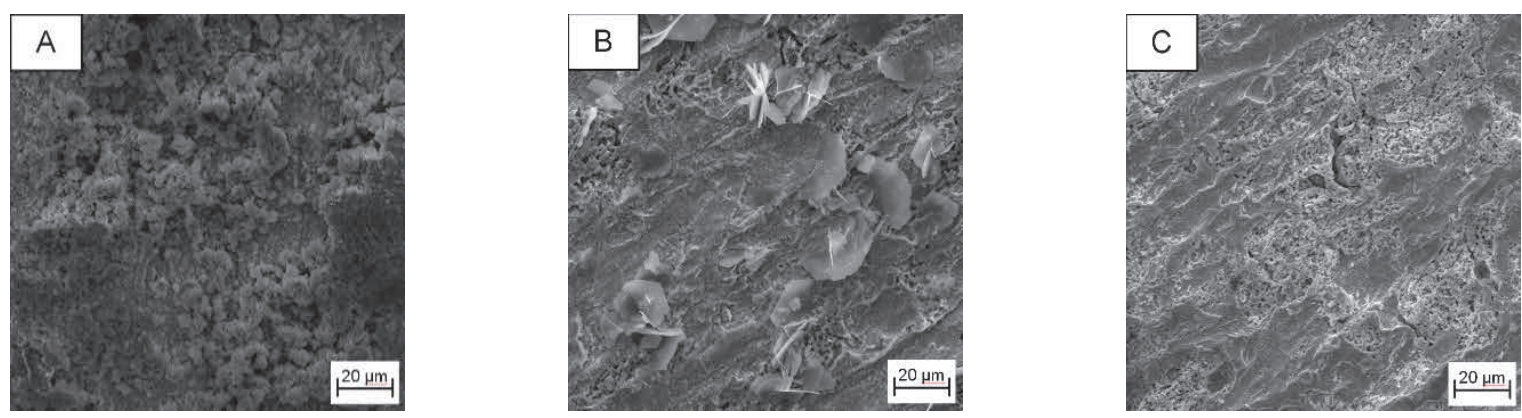

Figure 3 The SEM observation of artificially corroded lead samples after chemical treatment in $\mathrm{H}_{2} \mathrm{SO}_{4}(10 \%)$ solution (A), $\mathrm{CH}_{3} \mathrm{COOH}$ solution (B) and EDTA (3 \%) solution (C)

\section{CONCLUSION}

Examination of the lead samples after chemical treatment in different solutions showed that all used chemical treatments induced chemical and/or physical changes. Mainly the gloss lost and the surface roughness increase. The chemical treatment with $\mathrm{H}_{2} \mathrm{SO}_{4}$ solution induced the formation of a $\mathrm{PbSO}_{4}$ layer which acted as a corrosion barrier. Therefore, the $\mathrm{PbSO}_{4}$ layer caused non-recuperation of the original lead appearance. The $\mathrm{Na}_{3} \mathrm{PO}_{4} \cdot 12 \mathrm{H}_{2} \mathrm{O}$ solution and ion exchange resin did not remove the artificial corrosion product from lead surface. The chemical treatment with EDTA, $\mathrm{HCl}, \mathrm{CH}_{3} \mathrm{COOH}, \mathrm{CH}_{3} \mathrm{COONH}_{4}$ and $\mathrm{KNaC}_{4} \mathrm{H}_{4} \mathrm{O}_{6} \cdot 4 \mathrm{H}_{2} \mathrm{O}$ removed the artificial corrosion products on lead samples. The $\mathrm{CH}_{3} \mathrm{COONH}_{4}$ solutions were high aggressive to base lead during the chemical treatment. Moreover, highest concentration of $\mathrm{CH}_{3} \mathrm{COONH}_{4}$ solution brown tarnishing on lead surface induced. The chemical treatment with $\mathrm{CH}_{3} \mathrm{COOH}$ solution left an extremely active lead surface and due to the $\mathrm{CO}_{2}$ presence in atmosphere new corrosion products based on lead carbonates are formed. The chelating agent EDTA the remains of EDTA adsorbed on lead sample surface leaved. Depending on this study $\mathrm{HCl}$ and $\mathrm{KNaC}_{4} \mathrm{H}_{4} \mathrm{O}_{6} \cdot 4 \mathrm{H}_{2} \mathrm{O}$ appear as the most appropriate chemical treatment agents for lead carbonates removing.

\section{ACKNOWLEDGEMENTS}

\section{The authors gratefully acknowledge the financial support by the Czech Ministry of Culture under NAKI II programme (No. DG18P02OVV050).}

\section{REFERENCES}

[1] SCHOTTE, B. Study of electrolytic reduction of corroded lead objects and application, characterization and testing of a protective lead carboxylate coating. Thesis submitted in fulfilment of the requirements for the degree of Doctor in Science. Universiteit Gent: Faculty of Science. 2007.

[2] SELWYN, L. et al. Lead (Pb). In: SELWYN, Lyndsie. et al. Metals and Corrosion: A Handbook for the Conservation Professional. 1st ed. Canada: Canadian Conservation Institute. 2004. pp. 115-123.

[3] NOVÁK, P. Konzervování a restaurování olova a jeho slitin. In: Kolektiv autorů. Konzervování a restaurování kovů. 1 st ed. Brno: Technické muzeum v Brně. 2011. pp. 526-544. (in Czech)

[4] COSTA, V. and URBAN, F. Lead and its alloys: metallurgy, deterioration and conservation. Reviews in Conservation. 2005. vol. 6, pp. 48-62.

[5] STRACHOTOVÁ, K. Ch. and KOUŘIL, M. Vliv prítomnosti korozních produktů na korozní rychlost olova při expozici s papírovými obalovými materiály. Koroze a ochrana materiálu. 2018. vol. 62, no. 3, pp. 87-96, in Czech.

[6] SCHOTTE, B. and ADRIENS, A. The treatment of corroded lead artefacts. Studies in Conservation. 2006. vol. 51, pp. 1-8.

[7] COSTA, V. Electrochemistry as a conservation tool: an overview. In Conservation Science 2002. London: Archetype Publications. 2003. pp. 88-95. 
[8] COLES, E. L., GIBSON J. G. and HINDE, R. M. The corrosion of lead by dilute aqueous organic acids. J. Appl. Chem. 1958. pp. 341-348.

[9] TURGOOSE, S. The corrosion of lead and tin: before and after excavation. In Lead and Tin Studies in Conservation and Technology. United Kingdom Institute for Conservation: London. 1985. pp. 15-23.

[10] GIBSON, L. T. and WATT, C. M. Acetic and formic acids emitted from wood samples and their effect on selected materials in museum environments. Corrosion Science. 2010. vol. 52, pp. 172-178.

[11] Guidelines for the Storage and Display of Archaeological Metalwork [Online]. English heritage. 2013. pp. 12-13. [viewed 2018-04-22]. Available from: http://www.englishheritage.org.uk/content/learn/conservation/2543455/2543024/guidelines-for-the-storage-and-display-ofarchaeological-metalwork.pdf.

[12] MSALLAMOVÁ, Š. et al. Historical lead seals and the infuence of disinfectants on the lead corrosion rate. Heritage Science. 2019. vol. 7, no. 1, in print. 